\title{
Snail eggs as a raw material for the production of a caviar substitute
}

\author{
Monika Maćkowiak-Dryka, Krzysztof Szkucik, Renata Pyz-Łukasik ${ }^{凶}$ \\ Department of Food Hygiene of Animal Origin, Faculty of Veterinary Medicine, \\ University of Life Sciences in Lublin, 20-033 Lublin \\ renata.pyz@up.lublin.pl
}

Received: June 30, $2020 \quad$ Accepted: November 2, 2020

\begin{abstract}
Introduction: Snail eggs can be the raw material for the production of a caviar substitute. The substitute varies from the original in caloric value and nutrient content which determine the nutritional value of every foodstuff. The present study aimed to determine and compare the nutritional value and protein quality of eggs from two subspecies of edible snail. Material and Methods: The chemical composition of the snail eggs i.e. Cornu aspersum maxima and Cornu aspersum aspersum was determined in accordance with international standards. In order to evaluate the protein quality of the eggs of the two studied snail subspecies, the chemical score (CS), and a reference protein were used. Results: Significant differences in the content of water, ash, and carbohydrates, but comparable protein and fat contents and caloric values were found. Conclusion: The protein in the eggs of the snails was complete by the measure of the model adopted for this study, however, meeting the daily essential amino acid requirements of an adult would require an immense supply of both species' eggs. Snail eggs of the Cornu genus were characterised by much lower nutritional value in comparison with caviar and caviar substitutes.
\end{abstract}

Keywords: “white caviar”, snail eggs, Cornu aspersum, nutrients, amino acid.

\section{Introduction}

Caviar products are classified into six food categories, i.e. true caviar, substitute caviar, imitation caviar, simulated caviar, derivates and products only associated with caviar through their marketing. Caviar substitutes can be produced from the roe of fish other than acipenserids, as well as eggs of other non-fish species. At present, more than 38 species of fish and 3 species of other animals are used to produce these substitutes (3). An example of caviar produced from eggs of other animal species are the eggs of snails from the Cornu genus, which are the raw material for so-called "white caviar". The eggs of the Cornu aspersum species have a spherical shape and a milky-white, pearly colour, are not translucent, and measure $3-6 \mathrm{~mm}$ in diameter (26). The taste of "caviar" from eggs of these snail subspecies is described as earthy and nutty or oaky and of mushroom (14).

The nutritional value of a foodstuff is determined by nutrient content and caloric value (8). Studies regarding the chemical composition of caviar (beluga, imperial, and osetra) and its substitutes (red salmon roe and waxed mullet roe) showed different levels of major constituents and, therefore, varied caloric values. The ranges of content by component (g/100 g roe) were 24.0-27.3 for protein, 12.7-36.8 for fat, 21.2-52.0 for water, 4.1-8.3 for ash, and 4.6-8.3 for carbohydrate, and the range of the caloric values was $1224-2212 \mathrm{~kJ} / 100 \mathrm{~g}$ (17). In assessing the nutritional value of every foodstuff, the amino acid profile is important, especially the essential amino acid content (i.e. those that the organism is unable to synthesise on its own, and of which the only source is food). Essential amino acid levels $(\mathrm{mg} / 100 \mathrm{~g})$ in caviar and caviar substitutes were between 163 and 485 for isoleucine, 285 and 455 for leucine, 2647 and 6213 for lysine, 395 and 3038 for methionine, 160 and 669 for cystine, 114 and 494 for phenylalanine, 150 and 815 for tyrosine, 315 and 471 for threonine, 681 and 3296 for valine, 142 and 5274 for tryptophan, and 36 and 272 for histidine (17), which indicates varied protein quality in these products.

According to the literature data, production of alternative caviar products, i.e. caviar substitutes, has been following an upward trend (24), which points to the importance of this type of foodstuff in international 
trade. The literature describing the nutrient value of caviar substitutes contains little data regarding snail eggs.

The aim of the study presented in this paper was to determine and compare the nutritional value and protein quality of eggs of two subspecies of edible snail used in the production of caviar substitutes.

\section{Material and Methods}

Sample collection. The study material consisted of the raw eggs of two subspecies of edible snail, i.e. Cornu aspersum aspersum and Cornu aspersum maxima. After being extracted from soil, the snail eggs underwent preliminary treatment consisting of selection (choosing the eggs with the best quality characteristics) and washing. Study samples (100 g each) were delivered to the laboratory within $24 \mathrm{~h}$ of extraction and maintained in cold storage conditions $\left(0^{\circ} \mathrm{C}-4^{\circ} \mathrm{C}\right)$.

Proximate composition and amino acid composition. The chemical composition of the snail eggs was determined in accordance with international standards (at the accredited laboratory of University of Life Sciences in Lublin). Moisture content was measured by drying the samples in an oven at $103^{\circ} \mathrm{C} \pm 2^{\circ} \mathrm{C}$ to constant weight (20). Fat content was determined by the ether extraction method with a Tecator Soxtec System HT 21045 Extraction Unit (Foss Tecator AB, Sweden) (21). Ash content was established by sample incineration in a muffle furnace at $550^{\circ} \mathrm{C} \pm 25^{\circ} \mathrm{C}$ until the resultant ash was light grey in colour (22). Protein content was estimated by the Kjeldahl method $(\mathrm{N} \times 6.25)$ with a Tecator Kjeltec System 1026 distilling unit after acid digestion (Foss Tecator AB) (19). The carbohydrate content was derived by subtracting the percentages of moisture, fat, protein, and ash from $100 \%$ (12). The caloric value of the eggs was calculated to be $4 \mathrm{kcal} / \mathrm{g}$ for protein and carbohydrate and $9 \mathrm{kcal} / \mathrm{g}$ for fat (25).

Amino acid composition. The amino acid profile was obtained by high performance liquid chromatography (HPLC). The amino acid content in the samples (except for cystine, methionine, and tryptophan) was determined after acid hydrolysis with $6 \mathrm{~N} \cdot \mathrm{HCl}$ at $110^{\circ} \mathrm{C}$ for $20 \mathrm{~h}$ (4). Cystine and methionine were measured as cysteic acid and methionine sulphone, respectively, by performic acid oxidation before hydrolysis with $6 \mathrm{~N} \cdot \mathrm{HCl}$. Tryptophan was quantified using alkaline hydrolysis with $\mathrm{Ba}(\mathrm{OH})_{2}$ at $110^{\circ} \mathrm{C}$ for $20 \mathrm{~h}$. Chromatographic analysis was performed in an AAA 400 amino acid analyser
(Ingos, Czech Republic). The chromatograms were analysed using the CHROMuLAN V 0.88 programme (Pikron, Czech Republic) by comparison with the standard chromatogram. All chemical analyses were conducted in duplicate for each sample.

In order to evaluate protein quality in the eggs of the two studied snail subspecies, the chemical score (CS) and a reference protein were used; the CS was calculated as follows: $\% \mathrm{CS}=\mathrm{mg}$ of an amino acid in $1 \mathrm{~g}$ of the protein tested $/ \mathrm{mg}$ of the same amino acid in $1 \mathrm{~g}$ of the reference protein (5).

Statistical analysis. The obtained results were analysed statistically with SAS Enterprise Guide 5.1 (SAS Institute, USA) and expressed as the arithmetic means and standard deviation. The influence of each variability factor on the determined parameters was established using one-way analysis of variance (ANOVA) for groups for which the assumption of homogeneous variances was fulfilled. Tukey's test was incorporated for post-hoc analysis. The level of statistical significance was assumed to be $\mathrm{P} \leq 0.05$.

\section{Results}

The results of the presented study are shown in Tables 1-3. Significant differences $(P \leq 0.05)$ in major constituent contents in eggs of the two snail subspecies applied to water, ash (mineral ingredients), and carbohydrates. A higher level of water and lower levels of mineral ingredients and carbohydrates were found in the eggs of Cornu aspersum aspersum than in Cornu aspersum maxima. Amino acid content revealed differences in the quality of the protein from the studied snail eggs. Significant differences $(\mathrm{P} \leq 0.05)$ concerned both essential (methionine+cysteine, phenylalanine+tyrosine, and threonine) and non-essential (glutamic acid and proline) amino acid content. Higher levels of sulphur amino acids (methionine+cysteine) and aromatic amino acids (phenylalanine+tyrosine), and a lower level of threonine were found in the eggs of Cornu aspersum maxima. By contrast, the content of glutamic acid was higher and that of proline lower in the eggs of Cornu aspersum aspersum. The amino acids present in the smallest amount, designated the "limiting amino acids" for the protein in Cornu aspersum aspersum eggs, were leucine and valine (CS 135\% for both amino acids), and for Cornu aspersum maxima eggs it was leucine (CS 131\%).

Table 1. Major constituent content in eggs of Cornu aspersum aspersum and Cornu aspersum maxima

\begin{tabular}{lcccccc}
\hline \multirow{2}{*}{ Snail species } & \multicolumn{5}{c}{ Constituent content (\%) } \\
\cline { 2 - 6 } & Water & Fat & Protein & Ash & Carbohydrates \\
\hline CAA $(\mathrm{n}=10)$ & $87.78^{\mathrm{a}} \pm 1.52$ & $0.03^{\mathrm{a}} \pm 0.04$ & $4.16^{\mathrm{a}} \pm 0.15$ & $3.74^{\mathrm{b}} \pm 0.30$ & $4.28^{\mathrm{b}} \pm 1.31$ \\
CAM $(\mathrm{n}=10)$ & $86.0^{\mathrm{b}} \pm 1.02$ & $0.04^{\mathrm{a}} \pm 0.03$ & $4.31^{\mathrm{a}} \pm 0.16$ & $4.28^{\mathrm{a}} \pm 0.31$ & $5.34^{\mathrm{a}} \pm 1.46$ \\
\hline
\end{tabular}

CAA - Cornu aspersum aspersum; CAM - Cornu aspersum maxima; ${ }^{\text {a, b }}$ - means with different superscript letters in the same column differ significantly at $\mathrm{P} \leq 0.05$ 
Table 2. Essential amino acid content in the protein of Cornu aspersum aspersum and Cornu aspersum maxima eggs

\begin{tabular}{|c|c|c|c|}
\hline $\begin{array}{l}\text { Amino acid } \\
(\mathrm{g} / 100 \mathrm{~g} \text { protein })\end{array}$ & $\mathrm{CAA}(\mathrm{n}=6)$ & CAM $(n=6)$ & Standard* \\
\hline Histidine & $2.49^{\mathrm{a}} \pm 0.10$ & $2.47^{\mathrm{a}} \pm 0.09$ & 1.6 \\
\hline Isoleucine & $4.45^{\mathrm{a}} \pm 0.15$ & $4.22^{\mathrm{a}} \pm 0.13$ & 3.0 \\
\hline Leucine & $8.24^{\mathrm{a}} \pm 0.17$ & $7.98^{\mathrm{a}} \pm 0.11$ & 6.1 \\
\hline Lysine & $6.96^{\mathrm{a}} \pm 0.11$ & $6.97^{\mathrm{a}} \pm 0.25$ & 4.8 \\
\hline Methionine + cysteine & $3.10^{\mathrm{b}} \pm 0.09$ & $3.50^{\mathrm{a}} \pm 0.16$ & 2.31 \\
\hline Phenylalanine + tyrosine & $9.61^{b} \pm 0.39$ & $10.36^{\mathrm{a}} \pm 0.23$ & 4.12 \\
\hline Threonine & $6.12^{\mathrm{a}} \pm 0.16$ & $5.66^{\mathrm{b}} \pm 0.30$ & 2.5 \\
\hline Tryptophan & $5.40^{\mathrm{a}} \pm 0.82$ & $4.56^{\mathrm{a}} \pm 0.95$ & 0.66 \\
\hline Valine & $5.41^{\mathrm{a}} \pm 0.11$ & $5.65^{\mathrm{a}} \pm 0.11$ & 4.0 \\
\hline Total & $51.78^{\mathrm{a}} \pm 0.21$ & $51.37^{\mathrm{a}} \pm 0.32$ & 29.06 \\
\hline
\end{tabular}

CAA - Cornu aspersum aspersum, CAM - Cornu aspersum maxima, ${ }^{\mathrm{a}, \mathrm{b}}$ - means with different superscript letters in the same row differ significantly at $\mathrm{P} \leq 0.05$. ${ }^{*}$ Recommended amino acid scoring pattern for adult, ${ }^{1} \mathrm{Met}+\mathrm{Cys},{ }^{2} \mathrm{Phe}+\mathrm{Tyr}$ (29)

Table 3. Non-essential amino acid content in the protein of Cornu aspersum aspersum and Cornu aspersum maxima eggs

\begin{tabular}{lcc}
\hline $\begin{array}{l}\text { Amino acid } \\
(\mathrm{g} / 100 \text { g protein })\end{array}$ & CAA $(\mathrm{n}=6)$ & CAM $(\mathrm{n}=6)$ \\
\hline Asparaginic acid & $11.34^{\mathrm{a}} \pm 0.28$ & $11.43^{\mathrm{a}} \pm 0.38$ \\
Serine & $7.48^{\mathrm{a}} \pm 0.10$ & $7.34^{\mathrm{a}} \pm 0.17$ \\
Glutamic acid & $12.10^{\mathrm{a}} \pm 0.17$ & $11.54^{\mathrm{b}} \pm 0.20$ \\
Proline & $4.12^{\mathrm{b}} \pm 0.08$ & $4.75^{\mathrm{a}} \pm 0.28$ \\
Glycine & $3.49^{\mathrm{a}} \pm 0.02$ & $3.56^{\mathrm{a}} \pm 0.12$ \\
Alanine & $4.63^{\mathrm{a}} \pm 0.19$ & $4.72^{\mathrm{a}} \pm 0.07$ \\
Arginine & $5.05^{\mathrm{a}} \pm 0.17$ & $5.08^{\mathrm{a}} \pm 0.22$ \\
\hline Total & $48.2^{\mathrm{a}} \pm 0.16$ & $48.42^{\mathrm{a}} \pm 0.19$ \\
\hline
\end{tabular}

CAA - Cornu aspersum aspersum, CAM - Cornu aspersum maxima, a, b - means with different superscript letters in the same row differ significantly at $\mathrm{P} \leq 0.05$

\section{Discussion}

Based on the results of this research regarding the chemical content of Cornu aspersum aspersum and Cornu aspersum maxima eggs, significant differences in water $(87.78 \%$ and $86.03 \%$, respectively), ash $(3.74 \%$ and $4.28 \%$, respectively), and carbohydrate $(4.28 \%$ and $5.34 \%$, respectively) contents but comparable protein $(4.16 \%$ and $4.31 \%$, respectively) and fat $(0.03 \%$ and $0.04 \%$, respectively) contents were found. When compared to the eggs of Cornu aspersum maxima, the eggs of Cornu aspersum aspersum contained a water level higher by $2 \%$ but levels of mineral ingredients and carbohydrates lower by $3 \%$ and $20 \%$, respectively. These differences in the levels of major constituents did not result in differences in caloric values between the eggs of the two snail subspecies, and they all fell in the range of $34.04-38.90 \mathrm{kcal} / 100 \mathrm{~g}$. The low nutritional value of the studied snail eggs resulted from low levels of major constituents and low caloric value.

The results of the present research are comparable to those presented by Almeida (1) for the eggs of the large common garden snail, which showed $84.5 \%$ water, $6.7 \%$ carbohydrates, $5.0 \%$ ash, $3.7 \%$ protein, and $0.1 \%$ lipids. Other authors found much higher levels of protein in the dry mass of snail eggs of Helix aspersa maxima in a $34.6 \%-42.2 \%$ range (9). The high protein level was the result of using a high-energy and high-protein feed for the snails, and the differences in protein levels depended on the month of egg extraction. In view of the above, the subject literature notably lacks data regarding variability factors for the chemical composition of snail eggs and concomitant variability in the eggs' nutritional value. On the basis of the presented research results it may be shown that snail subspecies can be a variability factor for the chemical composition of Cornu aspersum eggs.

The protein and fat content in the eggs of the studied snail subspecies was severalfold lower than it was in caviar $(23.98 \%-31.13 \%$ and $10.90 \%-19.41 \%$, respectively) and fresh roe from different fish species (18.16\%-26.49\% and 3.39\%-7.74\%, respectively). However, water and carbohydrate contents in the eggs of both snail subspecies were higher than in caviar (37.1\%-53.02\% and 4.0\%, respectively) and other raw materials processed into caviar substitutes $(61.01 \%-$ $73.03 \%$ and $1.55 \%-2.81 \%)(7,11,15,18,27,29)$. The presented data indicate a lower nutritional value of the studied snail eggs than caviar and other raw materials used in caviar substitute production.

The variation in chemical composition of other raw materials used in caviar and caviar substitute production (fish roe) is mainly attributed to biological factors including species, maturity stages, harvest area and season $(2,13)$ and processing $(15,16)$. However, the impact of variability factors on the chemical composition of roe has no explicit pattern, and a good 
example of the inconsistency of the factors are the studies by Hamzeh et al. (10) regarding major constituents of the roe of the beluga sturgeon (Huso huso). They found no significant differences in protein, fat, water, or ash content between the roe from wild and the roe from farmed beluga sturgeon (protein $25.43 \%$ and $23.81 \%$, fat $14.8 \%$ and $15.67 \%$, water $56.21 \%$ and $57.29 \%$, and ash $1.73 \%$ and $1.60 \%$ ), which indicates that the habitat did not influence the content of these ingredients in the studied material.

Total essential amino acid levels in the studied snail eggs were comparable and their average was $51.58 \mathrm{~g} / 100 \mathrm{~g}$ protein. Regardless of the type of snail egg, the aromatics (phenylalanine and tyrosine) were present in the largest amount of all essential amino acids (9.61 and $10.36 \mathrm{~g} / 100 \mathrm{~g}$ protein). Next in order were leucine, lysine, threonine, valine, tryptophan, isoleucine, sulphur amino acids (methionine + cysteine), and histidine, which was the smallest amount present (2.47-2.49). The content of the listed essential amino acids (without tryptophan) was determined for caviar (from the family Acipenseridae) and caviar substitutes (Cyclopterus lumpus roe and Oncorhynchus keta roe) (23). After comparing the results of our research with the presented content of these amino acids in these products, differences of from $0.03 \mathrm{~g}$ to $2.3 \mathrm{~g}$ of amino acid/100 $\mathrm{g}$ protein were found (depending on amino acid), which indicated differences between the protein composition of the studied snail eggs and that of caviar and caviar substitutes. Comparison of essential amino acid composition in the protein of the studied snail eggs and Siberian sturgeon caviar also showed differences in protein composition. Among the amino acids from this group in the protein of the real caviar, leucine represented the largest amount, followed by lysine, the aromatic amino acids (phenylalanine+tyrosine), valine, isoleucine, threonine, sulphur amino acids (methionine+cysteine), and tryptophan (7).

According to $\mathrm{Wu}$ et al. (28), non-essential amino acids should also be considered in the concept of an "ideal" protein composition and when composing a balanced diet. Non-essential amino acid content is presented in Table 3. The totals of non-essential amino acids ( $\mathrm{g} / 100 \mathrm{~g}$ protein) in the protein from the eggs of the two studied snail subspecies were comparable $(\mathrm{P}>0.05 ; 48.21$ and 48.42). Among the amino acids from this group, the greatest amount yielded was of glutamic acid (12.10 and 11.54, respectively), next were aspartic acid, serine, arginine, alanine, and proline, and the smallest amount determined was that of glycine (3.49 and 3.56). The proteins in the eggs of Cornu aspersum aspersum differed from those in Cornu aspersum maxima in terms of the content of glutamic acid and proline, with disparity of $5 \%$ and $20 \%$, respectively.

In order to evaluate protein quality in the eggs of the two studied snail subspecies, the CS and a reference protein were used, i.e. the reference protein proposed by the FAO/WHO $(5,6)$. This reference specifies the daily requirement for essential amino acids for an adult person. When the contents of individual essential amino acids in the studied and reference proteins are compared, CS indicates the limiting amino acid. These were leucine and valine in the case of the protein in Cornu aspersum aspersum eggs (CS 135\% for both amino acids), and leucine in Cornu aspersum maxima eggs (CS 131\%). The CS values for limiting amino acids indicated their higher levels in the studied snail egg proteins in comparison with the standard. Comparison of the daily essential amino acid requirement determined for an adult person and the content of individual essential amino acids in the studied protein showed that approximately $100 \mathrm{~g}$ of protein from the eggs of either or both snail subspecies could fully cover the dietary need. However, due to the low protein content in the studied eggs of only $4.16 \%$ and $4.31 \%$, it would require a supply of more than $2,000 \mathrm{~g}$ of them. On the basis of the presented data, the nutritional value of studied snail eggs was low. Therefore, it seems justified to state that the eggs of the studied snail subspecies are no approximation of the raw material of caviar and are an imitation purely in their marketing.

In conclusion, snail eggs of Cornu aspersum aspersum and Cornu aspersum maxima contained small amounts of major constituents, which determined their low caloric value. The eggs of both snail subspecies were characterised by high quality protein; however, due to the low protein level in their composition, they could not be a foodstuff depended on to provide a significant share of the daily essential amino acid need for an adult person. The nutritional value of the studied snail eggs as a foodstuff was low. Snail subspecies is a variability factor for the chemical composition of eggs. Eggs of the studied snail subspecies were characterised by much lower nutritional and caloric values in comparison with caviar and selected caviar substitutes. Determining the variability factors and their influence on the chemical composition of snail eggs might enable a raw material to be obtained with a higher nutritional value, and should constitute the subject of further research.

Conflict of Interests Statement: The authors declare that there is no conflict of interests regarding the publication of this article.

Financial Disclosure Statement: The study was supported by the Ministry of Science and Higher Education project WKH/S/41/2020/WET of the University of Life Sciences in Lublin.

Animal Rights Statement: Not applicable.

\section{References}

1. Almeida G.N.: Caviar Pearl, study of physical-chemical and microbiological stability. Master's Dissertation in Food Security. Technical University of Lisbon, Faculty of Veterinary Medicine, Lisbon 2014

2. Bledsoe G.E., Bledsoe C.D., Rasco B.: Caviars and Fish Roe Products. Critical Rev Food Sci Nutr 2003, 43, 317-356. 
3. Bronzi P., Rosenthal H.: Present and future sturgeon and caviar production and marketing: A global market overview. J Appl Ichthyol 2014, 30, 1536-1546.

4. Davies M.G., Tomas A.J.: An investigation of hydrolytic techniques for the amino acid analysis of foodstuffs. J Sci Food Agricul 1973, 24, 1525-1540.

5. Food and Agriculture Organization of the United Nations: Protein quality evaluation. Report of Joint FAO/WHO Expert Consultation. FAO Food and Nutrition Paper, 1991, 51, 1-66.

6. Food and Agriculture Organization of the United Nations: Dietary protein quality evaluation in human nutrition - Report of an FAO Expert Consultation. FAO Food and Nutrition Paper, 2013, 92, 166.

7. Gong Y., Huang Y., Gao L., Lu J., Hu Y., Xia L., Huang H.: Nutritional composition of caviar from three commercially farmed sturgeon species in China. J Food Nutr Res 2013, 1, 108-112, doi: 10.12691/jfnr-1-5-5.

8. Government of the Republic of Poland: Ustawa $z$ dnia 25 sierpnia 2006 r. o bezpieczeństwie żywności i żywienia. Dz. U. 2006, 171, poz. 1225 .

9. Górka A., Oklejewicz B., Duda M.: Nutrient content and antioxidant properties of eggs of the land snail Helix aspersa maxima. J Nutr Food Sci 2017, 7, 594, doi: 10.4172/21559600.1000594.

10. Hamzeh A., Moslemi M., Karaminasab M., Khanlar M.A., Faizbakhsh R., Batebi Navai M., Tahergorabi R.: Amino acid composition of roe from wild and farmed Beluga sturgeon (Huso huso). J Agr Sci Tech 2015, 17, 357-364.

11. Intarasirisawat R., Benjakul S., Visessanguan W.: Chemical compositions of the roes from skipjack, tongol, and bonito. Food Chem 2011, 124, 1328-1334, doi: 10.1016/j.foodchem. 2010.07.076.

12. Jabeen F., Chaudhry A.S.: Chemical compositions and fatty acid profiles of three freshwater fish species. Food Chem 2011, 125, 991-996.

13. Kocatepe D., Turan H., Kaya Y., Erden R., Erdoğdu F.: Proximate chemical composition of whiting (Merlangius merlangus euxinus Nordmann, 1840) roe. J Aquat Food Prod Technol 2012, 21, 362-368, doi:10.1080/10498850.2011.602815.

14. Kolman R., Jankowska B., Kwiatkowska B., Georgian H., Michałowski L.: Caviar not only from sturgeon roes. Kom Ryb 2010, 4, 31-33

15. Machado T.M., Tabata Y.A., Takahashi N.S., Casarini L.M., Neiva C.R.P., Henriques M.B.: Caviar substitute produced from roes of rainbow trout (Oncorhynchus mykiss). Acta Sci Technol 2016, 38, 233-240, doi:10.4025/actascitechnol.v38i2.27944.
16. Maćkowiak-Dryka M., Pyz-Łukasik R., Ziomek M., Szkucik K.: Nutritional value of a new type of substitute caviar. Med Weter 2020, 76, 285-288, doi: dx.doi.org/10.21521/mw.6404.

17. Mol S., Turan S.: Comparison of proximate fatty acid and amino acid compositions of various types of fish roes. Int J Food Prop 2008, 11, 669-677, doi: 10.1080/10942910701611170.

18. Park K.S., Kang K.H., Bae E.Y., Baek K.A., Shin M.H., Kim D.U., Kang H.K., Kim K.J., Choi Y.J., Im J.S.: General and biochemical composition of caviar from Sturgeon (Acipenser ruthenus) farmed in Korea. Int Food Res J 2015, 22, 777-781.

19. Polish Committee for Standardization: PN-A-04018 1975. Agricultural foods products - Determination of nitrogen by the Kjeldahl method and expressing as protein. Polski Komitet Normalizacyjny, Warsaw, 1975.

20. Polish Committee for Standardization: PN-ISO 1442 2000. Meat and meat products - Determination of moisture content. Polski Komitet Normalizacyjny, Warsaw, 2000.

21. Polish Committee for Standardization: PN-ISO 1444 2000. Meat and meat products - Determination of free fat content. Polski Komitet Normalizacyjny, Warsaw, 2000.

22. Polish Committee for Standardization: PN-ISO 936 2000. Meat and meat products - Determination of total ash. Polski Komitet Normalizacyjny, Warsaw, 2000.

23. Rehbein H.: Caviare: proximate composition, amino acid content, and identification of fish species. Int J Food Res Technol 1985, $180,457-462$.

24. Sicuro B.: The future of caviar production on the light of social changes: a new dawn for caviar? Rev Aquacult 2019, 11, 204-219, doi: 10.1111/raq.12235.

25. Souci S.W., Fachmann W., Kraut H.: Food composition and nutrition tables. Medpharm, Scientific Publishers, Stuttgart 2000.

26. Szkucik K., Ziomek M., Maćkowiak-Dryka M., Paszkiewicz W.: Edible snails - their performance, nutritive value and safety for consumers. Życie Wet 2011, 86, 631-635.

27. Wirth M., Kirschbaum F., Gessner J., Krüger A., Patriche N., Billard R.: Chemical and biochemical composition of caviar from different sturgeon species and origins. Nahrung 2000, 44, 233-237, doi: 10.1002/1521-3803(20000701)44:4<233::AID-FOOD233>3.0.CO;2-1.

28. Wu G., Wu Z., Dai Z., Yang Y., Wang W., Liu C., Wang B., Wang J., Yin Y.: Dietary requirements of "nutritionally nonessential amino acids" by animals and humans. Amino Acids 2013, 44, 1107-1113, doi: 10.1007/s00726-012-1444-2.

29. Zdrojewicz Z., Wróblewska M., Tomaszewski Ł.: Caviar-luxury or health? Med Rodz 2016, 19, 201-206. 